EGG-WTD-9684
Auguet 1991

INFORMAL REPORT

\section{THE PRODUCTION OF LOW-ENERGY NEUTRONS FOR THE RHMMS}

E. B. Nieschmidt

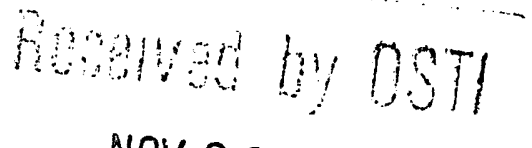

NOV 221991

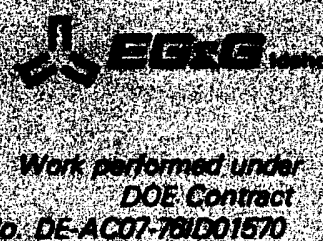




\section{DISCLAIMER}

This book was prepared as an account of work sponsored by an agency of the United States Government. Neither the United States Government nor any agency thereof, nor any of their employees, makes any warranty, express or implied, or assumes any legal liabilit, or responsibility for the accuracy. completeness, or usefulness of any information, apparatus, product or process disclosed, or represents that its usa would not infringe privately owned rights. References herein to any specific commercial product, process, or service by trade name, trademark, manufacturer, or otherwise, does not necessarily constitute or imply its endorsement, recommendation, or favoring by the United States Government or any agency thereof. The views and opinions of authors expressed herein do not necessarily state or reflect those of the United Sticies Government or any agency thereof. 


\title{
THE PRODUCTION OF LOW-ENERGY NEUTRON FOR THE RHMMS
}

\author{
E. B. Nieschmidt
}

Published August 1991

\section{Idaho National Engineering Laboratory EG\&G Idaho, Inc. \\ Idaho Falls, Idaho 83415}

\section{Prepared for the \\ U.S. Department of Energy \\ Office of Environmental Restoration and Waste Management Under DOE Contract No. DE-AC07-76ID01570}




\title{
THE PRODUCTION \\ OF \\ LOW ENERGY NEUTRONS \\ FOR THE RHMMS
}

\author{
E. B. NIESCHMIDT
}

Reviewed by:

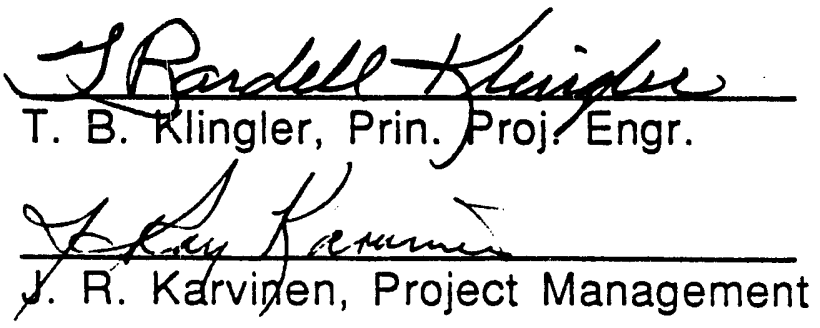

$\frac{5 \cdot 21-21}{\text { Date }}$

$\frac{5-28-9)}{\text { Date }}$

$\frac{2}{\text { K. P. Lange, Projects }}$

$\frac{\text { c. 3-y1 }}{\text { Date }}$ 


\begin{abstract}
Neutron interrogation is used in both the active neutron measurement cell for the identification of fissile materials and in the hazardous material cell for the capture gamma identification of the hazardous elements in waste. The use of radiological neutron sources and neutron generators, using the deuterium/tritium or deuterium/deuterium reactions for neutron production, results in the production of high energy neutrons. For most materials the high absorption cross sections are in the neutron thermal energy range. The moderation of the high energy reutrons to provide a high ratio thermal/epithermal spectrum is difficult. The effort herein reported seeks to find methods of producing neutrons at much lower energy levels, preferably below $200 \mathrm{KeV}$.
\end{abstract}


CONTENTS

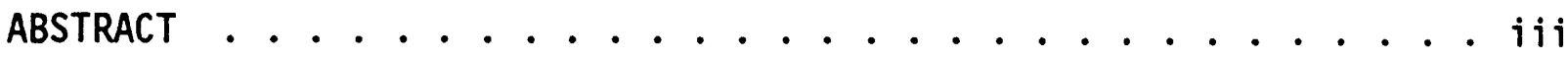

ACRONYMS ........................ . vi

INTRODUCTION . . . . . . . . . . . . . . . . . . . 1

THERMAL NEUTRON PRODUCTION ................... 2

CONCLUSIONS . . . . . . . . . . . . . . . . . . . 5

REFERENCES ......................... 6

TABLES

1. Neutron mean free paths in water .............. 3

2. Reaction $Q$ values for various target materials and projectiles...................... . 4

v 


\section{ACRONYMS}

$\begin{array}{ll}\alpha & \text { alpha } \\ d & \text { deuteron } \\ n & \text { neutron } \\ p & \text { proton }\end{array}$

RHMMS Radiological and Hazardous Material Monitoring System TRU transuranic 


\section{THE PRODUCTION OF LOW-ENERGY NEUTRONS}

FOR THE RHMMS

\section{INTRODUCTION}

In support of research and development programs related to the Radiological and Hazardous Material Monitoring System (RHMMS), certain materials have been selected for use as neutron producing targets. The purpose of these targets is to produce low-energy neutrons to use as probes for the detection and assay of transuranic (TRU) materials. The use of thermal neutrons as an interrogation particle and the subsequent gamma-ray detection has been discussed by T. B. Klingler.' 


\section{THERMAL NEUTRON PRODUCTION}

A thermal spectrum is produced by moderating neutrons colliding with light nuclei, such as hydrogen or deuterium. The hydrogen isotopes are usually incorporated into water or polyethylene. However, a true thermal spectrum is almost impossible to obtain if there is a component of high-energy neutrons in the source spectrum. The reason for this is that the scattering cross-section for higher energy neutrons is small and, consequently, the moderator has little effect in reducing their energy. In addition, a large number of collisions is required to reduce the energy to thermal.

The magnitude of this problem is illustrated in Table 1 where the mean free paths of neutrons and the approximate number of collisions required to reach thermal energies in water is shown. The hydrogen density in water is taken to be $6.69 \times 10^{22}$ nuclei $/ \mathrm{cm}^{3}$. A review of Table 1 emphasizes that to achieve a near thermal neutron spectrum, one must start with a low-energy source spectrum.

Low-energy neutrons can be produced by negative $Q$ reactions between charged particles and target materials. Examples of such rections are $(p, n)$, $(d, n),(\alpha, n)$, etc. Some of these reactions are usually positive $Q$ but $(p, n)$ are almost always negative $Q$. Using negative $Q$ reactions one may obtain neutron energies which are approximately the sum of the proton energy and the $Q$ value.

Target materials considered are 1 isted in Table 2, along with their $Q$ value energies for $(p, n)$ and other reactions. The Idaho State University Van De Graaff accelerator was used with ${ }^{51} \mathrm{~V},{ }^{55} \mathrm{Mn}$, and ${ }^{19} \mathrm{~F}$ targets to verify the predictions. 
Tabie 1. Neutron mean free paths in water

\begin{tabular}{|c|c|c|c|c|}
\hline \multirow[t]{2}{*}{$E_{n}(e V)$} & \multirow[t]{2}{*}{ MFP ${ }^{1} \mathrm{H}(\mathrm{cm})$} & \multirow[t]{2}{*}{$\mathrm{MPF}^{2} \mathrm{D}(\mathrm{cm})$} & \multicolumn{2}{|c|}{$\begin{array}{c}\text { Approximate } \\
\text { Collisions to Thermal }\end{array}$} \\
\hline & & & ${ }^{1} \mathrm{H}$ & $\underline{2} D$ \\
\hline 0.100 & 0.63 & 3.8 & 2 & 2. \\
\hline 0.300 & 0.63 & 3.8 & 4 & 4 \\
\hline 0.800 & 0.65 & 4.0 & 5 & 6 \\
\hline 1.00 & 0.67 & 4.1 & 5 & 6 \\
\hline 10 & 0.72 & 4.4 & 9 & 10 \\
\hline 100 & 0.73 & 4.4 & 12 & 14 \\
\hline 1000 & 0.74 & 4.4 & 15 & 18 \\
\hline $10^{4}$ & 0.81 & 4.5 & 19 & 22 \\
\hline $10^{5}$ & 1.42 & 4.5 & 22 & 26 \\
\hline $10^{6}$ & 4.40 & 4.7 & 25 & 30 \\
\hline $10^{7}$ & 16.7 & 5.5 & 28 & 34 \\
\hline
\end{tabular}


Table 2. Reaction $Q$ values for various target materials and projectiles

\begin{tabular}{|c|c|c|c|}
\hline \multirow[t]{2}{*}{ Target } & \multicolumn{3}{|c|}{$Q(\mathrm{MeV})$} \\
\hline & $(p, n)$ & $(d, n)$ & $(\alpha, n)$ \\
\hline${ }^{7} L i$ & -1.64 & 4.21 & -2.79 \\
\hline${ }^{9} \mathrm{Be}$ & -1.85 & 4.00 & 5.70 \\
\hline${ }^{19} \mathrm{~F}$ & -4.02 & 1.82 & -12.32 \\
\hline${ }^{45} \mathrm{SC}$ & -2.34 & 2.96 & -2.24 \\
\hline${ }^{51} \mathrm{~V}$ & -1.53 & 4.32 & -2.29 \\
\hline${ }^{55} \mathrm{Mn}$ & -1.01 & 4.84 & -5.88 \\
\hline
\end{tabular}

Review of Table 2 leads to the following conclusions:

- For these high yield target materials the $(p, n)$ reactions are the most favorable when using a small (approximately $2 \mathrm{MV}$ ) accelerating potential. Any of the materials considered, with the exception of ${ }^{45} \mathrm{Sc}$ and ${ }^{19} \mathrm{~F}$, are suitable. The $(p, n)$ reaction on ${ }^{19} \mathrm{~F}$ does not interfere when using a LiF target.

- None of the $(d, n)$ reactions are suitable for achieving low-energy neutrons, but may be useable if high-energy neutrons are desired. The most favorable of these reactions is ${ }^{9} \mathrm{Be}(d, n)^{10} \mathrm{~B}$ which is very prolific.

- None of the $(\alpha, n)$ reactions are suitable for low-energy neutrons. However, the ${ }^{9} \mathrm{Be}(\alpha, n)^{12} \mathrm{C}$ reaction produces copious amounts of higher-energy neutrons.

When thick targets are used, neutrons with energies are obtained from just above zero to the value of the particle energy plus the reaction $Q$. 


\section{CONCLUSIONS}

Assuming the use of a reasonably small (approximately 2 MV) accelerator, a target using $(p, n)$ reactions should be used. Among the materials listed in Table 2, the best neutron producers are ${ }^{7} \mathrm{Li}$ and ${ }^{9} \mathrm{Be}$. It is recommended that Be and Li nitride (or fluoride) be considered as the selected target materials. As a second choice, ${ }^{51} \mathrm{~V}$ is the best candidate. 


\section{REFERENCES}

1. T. B. Klingler, EGG-WM-8948 Rev 1, (September, 1990). 

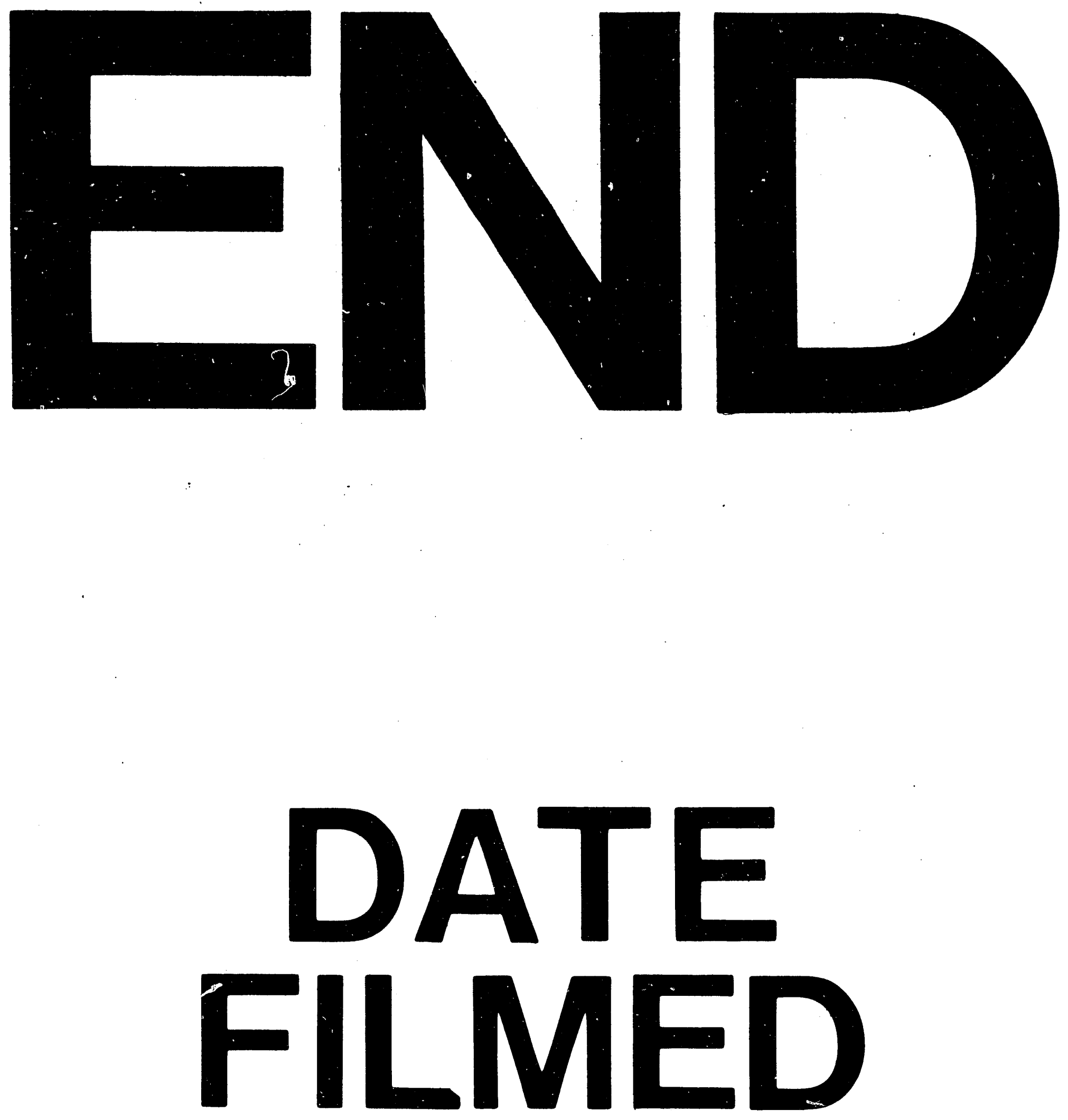

1

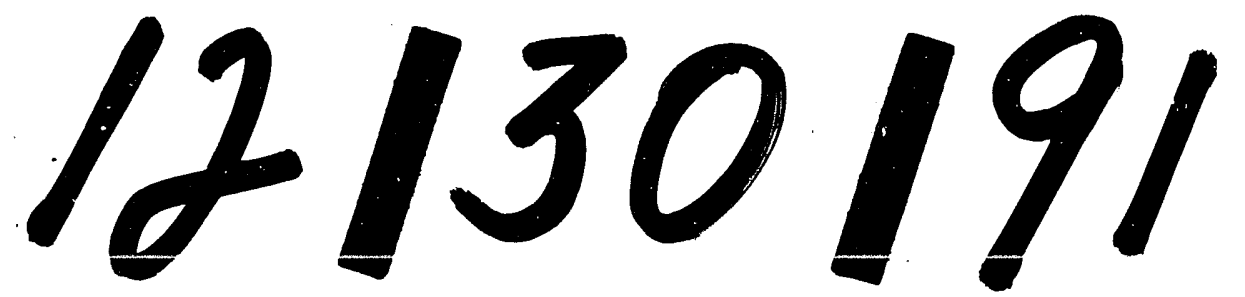

T 
